\section{Softening and Ripening of 'Athena' Cantaloupe (Cucumis melo L. var. reticulatus) Fruit at Three Harvest Maturities in Response to the Ethylene Antagonist 1-methylcyclopropene}

\author{
Jiwon Jeong, James Lee, and Donald J. Huber ${ }^{1}$ \\ Horticultural Sciences Department, Institute of Food and Agricultural \\ Sciences, University of Florida, 1213 Fifield Hall, Gainesville, FL 32611
}

Additional index words. climacteric, fruit ripening, 1-MCP, softening, storage life

\begin{abstract}
Three experiments were performed to characterize the physiological responses of an Eastern United States shipper muskmelon (Cucumis melo $\mathrm{L}$. var. reticulatus 'Athena') harvested preripe (1/4 slip) and during ripening (half-slip, full-slip) to $1 \mu L^{\prime} \cdot L^{-1}$ 1-methylcyclopropene (1-MCP), a potent ethylene antagonist effective at significantly extending the time required for climacteric fruit to complete ripening. In the first experiment, preripe fruit were treated with 1-MCP $\left(18\right.$ hour, $\left.20^{\circ} \mathrm{C}\right)$ before storage at $15^{\circ} \mathrm{C}$. Softening of preripe 'Athena' was significantly suppressed in response to $1-\mathrm{MCP}$, with firmness of control and $1-\mathrm{MCP}$-treated fruit declining $\approx 50 \%$ and $\approx \mathbf{3 6} \%$ through 12 and 18 days of storage at $15{ }^{\circ} \mathrm{C}$, respectively. By 21 days of storage, firmness of 1-MCP-treated remained near $70 \mathrm{~N}$, minimally within the upper range of whole-fruit firmness values considered acceptable for consumption (50-75 N). Fruit treated with 1-MCP exhibited significantly lower ethylene production, respiratory rates, and electrolyte leakage throughout storage. In a second experiment, muskmelon were treated with 1-MCP $\left(18\right.$ hours, $\left.20^{\circ} \mathrm{C}\right)$ at progressively advanced stages of ripening (half- and fullslip stages). Softening was significantly suppressed in half-slip fruit, declining $\approx 64 \%$ and $\approx 23 \%$ in control and 1-MCP-treated fruit, respectively, during 16 days of storage at $15{ }^{\circ} \mathrm{C}$. Advanced-ripening, full-slip fruit were similarly affected, softening $\approx 60 \%$ and $\approx 25 \%$ in control and 1-MCP-treated fruit, respectively, during 10 days at $15^{\circ} \mathrm{C}$. In a third experiment designed to simulate possible commercial handling protocols, full-slip muskmelon were treated with 1-MCP $\left(24\right.$ hours, $\left.10^{\circ} \mathrm{C}\right)$ and held at $10^{\circ} \mathrm{C}$ for 5 days before transfer to $20^{\circ} \mathrm{C}$. Mesocarp firmness of 1-MCP and control fruit within 2 days of transfer to $20{ }^{\circ} \mathrm{C}$ had decreased $\approx 40 \%$ and $\approx 54 \%$, respectively, compared with values at the start of the experiment. After an additional 2 days at $20{ }^{\circ} \mathrm{C}$, the mesocarp tissue of the respective treatments had softened $42 \%$ and $70 \%$. Fruit treated with the ethylene antagonist showed significantly delayed incidence of surface decay and sunken regions compared with control fruit.
\end{abstract}

Cantaloupe (Cucumis melo L.) melons of the Reticulatus Group, commonly known as cantaloupes or muskmelons, are climacteric fruits in which ripening is highly coordinated by ethylene and have a relatively short storage life (Seymour and McGlasson, 1993). Cantaloupe fruits are marketed soon after harvest unless they are at a very early stage $(1 / 4 \mathrm{slip})$ of maturity. This is especially true for the Eastern type muskmelons, grown throughout the Eastern United States and destined for local, fresh-market consumption. Western-type muskmelons, grown primarily in California, Arizona, and Texas, are less

Received for publication 18 Jan. 2007. Accepted for publication 14 Mar. 2007.

This research was supported, in part, by contributions from Agro-Fresh Inc. and by a grant from the USDA Program in Tropical Agricultural Research (T-STAR).

${ }^{1}$ To whom reprint requests should be addressed; e-mail djhuber@ufl.edu initiation. The rapid response to and capacity to recovery from the effects of 1-MCP applied after ripening initiation provide opportunities to allow fruit to reach more advanced ripening and higher inherent quality before harvest.

The objective of this study was to characterize physiological responses of preripe ( $1 / 4$ slip) and ripening (half- and full-slip) 'Athena' muskmelon melon (an Eastern type) to 1-MCP.

\section{Materials and Methods}

Plant material. Cantaloupe (C. melo L. var. reticulatus) fruit ('Athena') were harvested from field-grown plants at the North Florida Research and Education CenterSuwannee Valley, Live Oak, FL. This study included three experiments performed over a two-season period. In the first season, fruit were harvested at a preripe ( $1 / 4 \mathrm{slip})$ stage of development (Exp. 1). The subsequent two experiments were performed during the following season using half-slip or full-slip fruit (Exp. 2 and 3). Developmental classification was judged as 1) preripe-maximum $1 / 4$ slip; 2) half-slip — stem scar without clean break; and 3) full-slip - clean stem-scar break, full net development.

After transfer to the postharvest research facilities in Gainesville, fruit were selected on the basis of uniformity of size, freedom from defects, and the status of the abscission zone. The fruit were then washed with tap water, dipped in $200 \mu \mathrm{L} \cdot \mathrm{L}^{-1}$ free chlorine in tap water $(\mathrm{pH} 8.0)$ for $1 \mathrm{~min}$, and air-dried (Expts. 1 and 2). In Expt. 3, fruit were not subjected to surface washing or sanitation procedures. Field packing of muskmelons in Florida is not consistently accompanied by surface washing (Sargent, personal communication).

1-MCP application. Twenty fruit were placed in 174-L containers and exposed to $1-\mathrm{MCP}$ by releasing the gas from a commercial powdered formulation (SmartFresh, Agro-Fresh, Philadelphia, PA). The concentration selected $\left(1.0 \mu \mathrm{L} \cdot \mathrm{L}^{-1}\right)$ was achieved through addition of $320 \mathrm{mg}$ of powder ( $0.14 \%$ formulation) to $100 \mathrm{~mL}$ of tap water following manufacturer's instructions. 1-MCP treatments (Expt. 1 and Expt. 2) were performed for $18 \mathrm{~h}$ at $20{ }^{\circ} \mathrm{C}$ and $85 \%$ relative humidity (RH). Immediately following 1-MCP treatment, fruit were removed from the containers and transferred to $15^{\circ} \mathrm{C}$ facilities for ripening. Control fruit were maintained under identical storage conditions.

Experiment 3 was designed to simulate commercial handling protocols and storage conditions. Full-slip fruit were treated with 1-MCP $\left(1.0 \mu \mathrm{L} \cdot \mathrm{L}^{-1}\right)$ for $24 \mathrm{~h}$ at $10{ }^{\circ} \mathrm{C}$, stored at $10^{\circ} \mathrm{C}$ for $5 \mathrm{~d}$, and then transferred to $20^{\circ} \mathrm{C}$. Fruit integrity was assessed on the basis of mesocarp firmness during storage at $20{ }^{\circ} \mathrm{C}$. Decay incidence and other visible disorders (sunken areas on fruit surface) were also monitored.

Respiration, ethylene, and 1-MCP measurements. Fruit (5 fruit per treatment) 
were sealed individually in $3.6-\mathrm{L}$ plastic containers for $1 \mathrm{~h}$ at $20{ }^{\circ} \mathrm{C}$. For $\mathrm{CO}_{2}$ determination, $0.5 \mathrm{~mL}$ of headspace gas was analyzed on a Gow-Mac gas chromatograph (Series 580, Bridgewater, NJ) equipped with a thermal conductivity detector (TCD). The carrier gas (helium) flow rate was $30 \mathrm{~mL} \cdot \mathrm{min}^{-1}$. The oven was set at $40{ }^{\circ} \mathrm{C}$ and the detector and injector were operated under ambient conditions $\left(23-24{ }^{\circ} \mathrm{C}\right)$. For $\mathrm{C}_{2} \mathrm{H}_{4}$, $1 \mathrm{~mL}$ of headspace gas was analyzed using a FID gas chromatograph (Hewlett-Packard 5890, Avondale, PA) equipped with an activated alumina SS column (Supelco, Bellefonte, PA). Injector, oven, and detector were operated at 200,70 , and $250^{\circ} \mathrm{C}$, respectively. 1 -MCP concentrations in the 174-L treatment containers were measured using a FID gas chromatograph (HP 5890) equipped with an 80-100 mesh Chromosorb PAW stainless steel column (Supelco). Injector, oven, and detector were operated at 150,70 , and $200{ }^{\circ} \mathrm{C}$, respectively. Isobutylene, which has a FID response similar to that of 1-MCP (Jiang et al., 1999), was used to quantify the levels of 1-MCP in the treatment chambers.

Firmness. Whole-fruit firmness (measured in N) was determined using an Instron Universal Testing Instrument (Model 4411, Canton, MA) fitted with a 5-cm diameter, flat-plate probe and $50-\mathrm{kg}$ load cell. After establishing zero-force contact between the probe and the equatorial region of the fruit, the probe was driven with a crosshead speed of $10 \mathrm{~mm} \cdot \mathrm{min}^{-1}$. The force $(\mathrm{N})$ was recorded at $2.0-\mathrm{mm}$ deformation and was determined at two equidistant points on the equatorial region of each fruit. Mesocarp firmness (Expt. 3) was measured on halved fruit using the Instron Universal Testing Instrument fitted with a $7-\mathrm{mm}$ convex probe and $5-\mathrm{kg}$ load cell. The probe was driven to a depth of $3 \mathrm{~mm}$ at a crosshead speed of $30 \mathrm{~mm} \cdot \mathrm{min}^{-1}$. Three mesocarp firmness measurements were performed on each fruit half.

Electrolyte leakage. Mesocarp cylinders ( 5 cylinders per fruit) $8 \mathrm{~mm}$ in diameter were removed from the equatorial mesocarp tissue using a cork borer. The cylinders were trimmed to produce disks of 8 -mm thickness using the centermost region of each cylinder. Disks ( 5 per fruit) were rinsed briefly with deionized water and blotted on a slightly moistened Whatman filter paper followed by incubation in $15 \mathrm{~mL}$ of $500 \mathrm{~mm}$ mannitol for $4 \mathrm{~h}$ in a capped polypropylene tube $(50 \mathrm{~mL})$. Conductivity was measured immediately after addition of the disks to the 500 mM mannitol solution and following the 4-h incubation period with a conductivity bridge (YSI-31A, Yellow Springs Instrument Co., Yellow Springs, OH) equipped with a conductivity cell (Model 3403, Yellow Springs Instrument Co.). For total electrolyte determination, the disks and bathing solution after $4 \mathrm{~h}$ were stored at $-20{ }^{\circ} \mathrm{C}$ for at least $24 \mathrm{~h}$, thawed, heated in a boiling water bath for $30 \mathrm{~min}$, cooled to room temperature, and conductivity measured. Electrolyte leakage was expressed as a percentage of mesocarp total electrolyte content.
Soluble solids concentration. At selected intervals during storage, fruit were peeled, diced, placed in polyethylene bags, and stored at $-20{ }^{\circ} \mathrm{C}$ until analyzed. Partially thawed mesocarp tissue ( $80 \mathrm{~g}$ ) was homogenized (Polytron) and centrifuged at $12,000 \mathrm{~g}$ for $20 \mathrm{~min}$ at $20{ }^{\circ} \mathrm{C}$. Soluble solids concentration (SSC) in the supernatant was determined using a digital refractometer (Abbe Mark-10480, Buffalo, NY).

Statistical analysis. The experiments were conducted using a completely random- ized design. Statistical procedures were performed using the PC-SAS software package (SAS Institute, 1985). Data were subjected to ANOVA using the General Linear Model (Minitab, State College, PA).

\section{Results and Discussion}

1-MCP Treatment of preripe 'Athena' cantaloupe. Control preripe ( $1 / 4 \mathrm{slip}$ ) 'Athena muskmelon softened $\approx 50 \%$ over a 12 -d period at $15{ }^{\circ} \mathrm{C}$, from initial values of

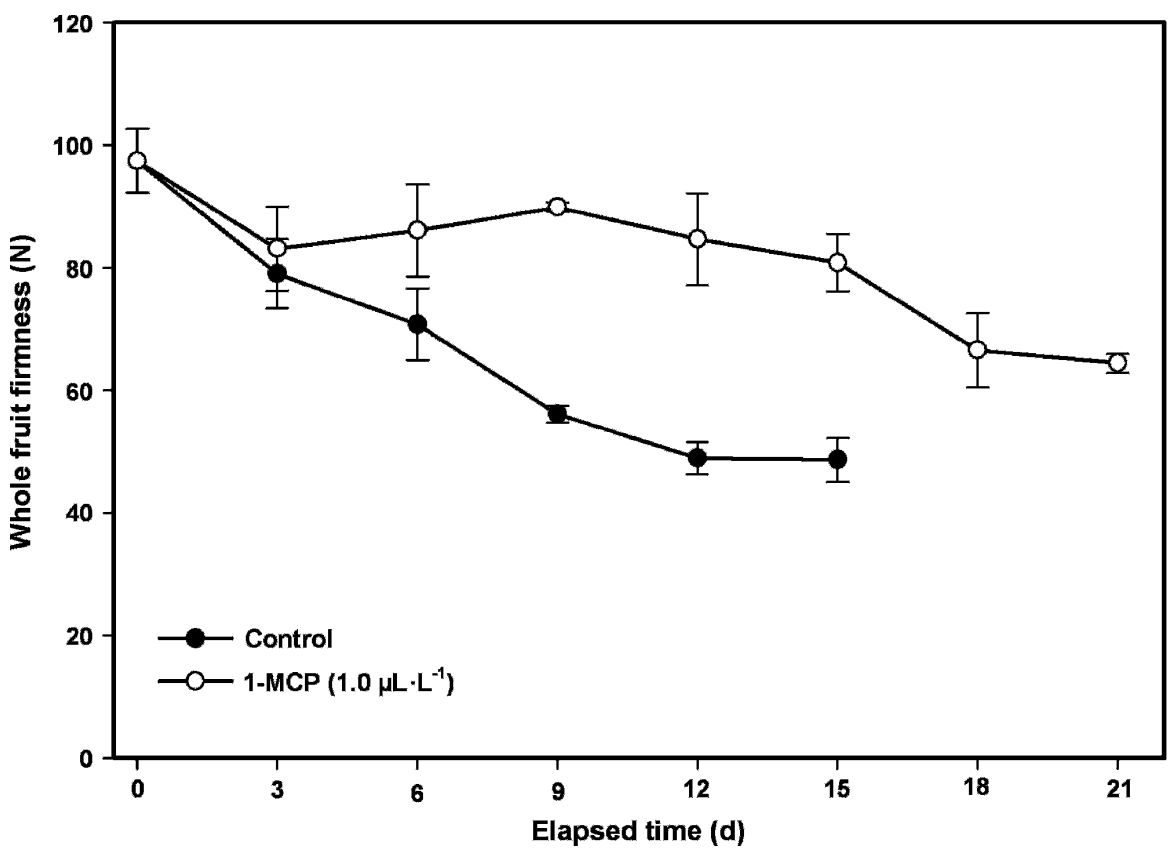

Fig. 1. Whole-fruit firmness $(\mathrm{N})$ of preripe 'Athena' muskmelon treated with air (control) or 1-MCP at $1.0 \mu \mathrm{L} \cdot \mathrm{L}^{-1}$ for $18 \mathrm{~h}$ at $20^{\circ} \mathrm{C}$ and stored at $15^{\circ} \mathrm{C}$. Vertical bars are standard deviations of means $(n=30$, 15 fruit, 2 measurements per fruit).

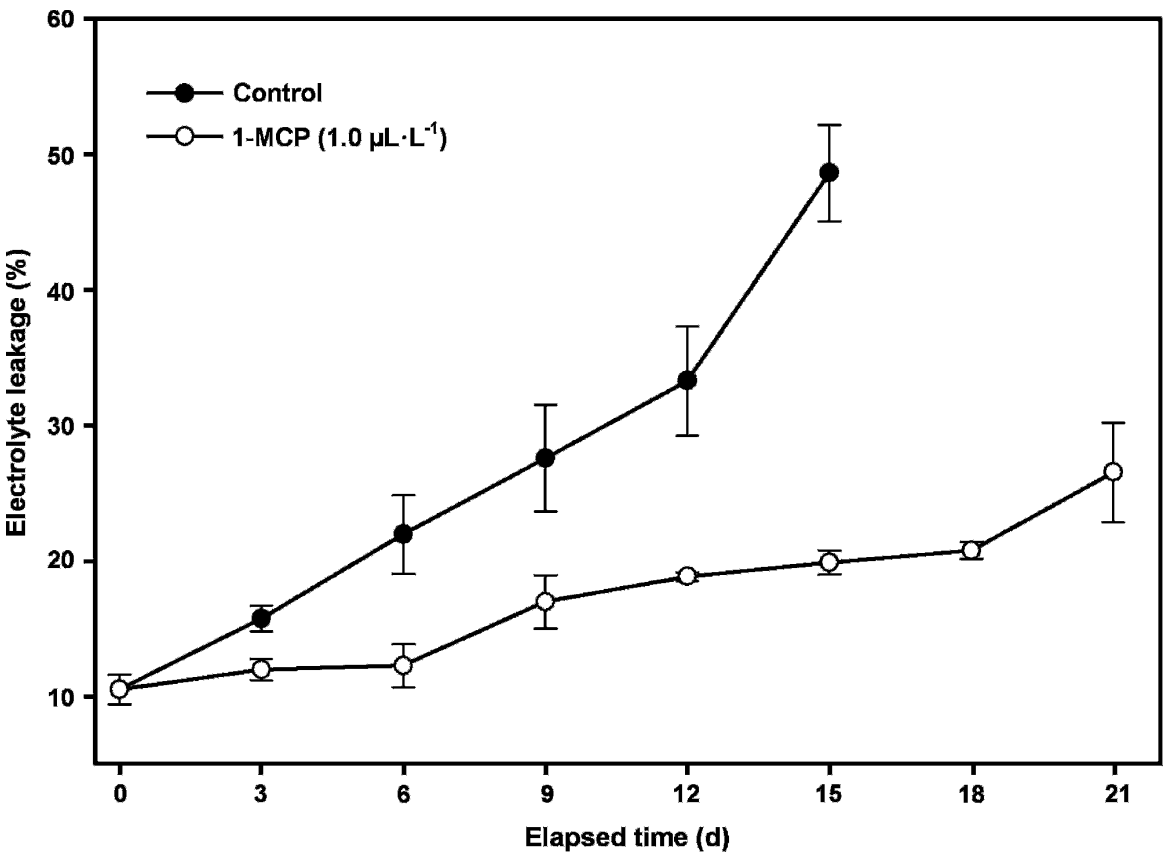

Fig. 2. Electrolyte leakage (\%) of mesocarp tissue from preripe 'Athena' muskmelon treated with air (control) or 1-MCP at $1.0 \mu \mathrm{L} \cdot \mathrm{L}^{-1}$ for $18 \mathrm{~h}$ at $20^{\circ} \mathrm{C}$ and stored at $15{ }^{\circ} \mathrm{C}$. Vertical bars are standard deviations of means $(n=5)$. 
$97.4 \pm 5.2 \mathrm{~N}$ (firm to extremely firm) to $\approx 48.6$ $\pm 3.6 \mathrm{~N}$ (extremely soft) (Fig. 1). Softening was significantly delayed and suppressed in response to $1.0 \mu \mathrm{L} \cdot \mathrm{L}^{-1} 1-\mathrm{MCP}$, with wholefruit firmness declining $\approx 18 \%$ through $12 \mathrm{~d}$ and $35 \%$ after $21 \mathrm{~d}$ of storage.

Softening of muskmelon melons has been attributed to changes in properties of the plasma membrane, typically reflected as rapid increases in mesocarp electrolyte leakage (Flores et al., 2001; Lacan and Baccou, 1996; Lester, 1996; Lester and Stein, 1993). Turgor changes, possibly reflecting altered membrane properties, have also been proposed to contribute to softening in ripening tomato fruit (Shackel et al., 1991). Electrolyte leakage in control preripe 'Athena' fruit increased linearly to $\approx 33 \%$ through the first $12 \mathrm{~d}$ of storage, thereafter increasing markedly to $\approx 50 \%$ between 12 and $15 \mathrm{~d}$ (Fig. 2). Tissue exhibiting leakage values near $50 \%$ typically appeared translucent and watersoaked, conditions that in other fruits of the Cucurbitaceae, including watermelon (Citrullus lanatus Thunb. Matsum and Nakai), have been associated with enhanced membrane-lipid catabolism (Mao et al., 2004). Leakage values in 1-MCP-treated fruit remained at or below $20 \%$ through $18 \mathrm{~d}$, and these fruit did not develop watersoaking within the storage periods employed. The strong influence of 1-MCP in suppressing electrolyte leakage in 'Athena' muskmelon was similar to its effects on 'Galia' melon (Ergun et al., 2005). In contrast, 1-MCP was minimally effective in suppressing ion leakage in banana (Musa sp.; Jiang et al., 2004) and intact and fresh-cut tomato (Jeong et al., 2004) fruits. In the nonclimacteric watermelon, 1-MCP prevented electrolyte leakage increases only in fruit challenged with exogenous ethylene (Mao et al., 2004). Whether increased ion leakage does reflect events that contribute to fruit softening in general is uncertain. In one ('Pinkerton') of three varieties of avocado (Persea americana Mill.) fruit examined (Hershkovitz et al., 2005), for example, 1-MCP completely negated increases in mesocarp ion leakage during ripening, yet the rate and magnitude of softening were only delayed.

Ethylene production in control muskmelons increased rapidly after $3 \mathrm{~d}$ of storage (Fig. 3A). Fruit treated with 1-MCP showed significantly reduced ethylene production rates (Fig. 3A) that remained below those of control fruit throughout $21 \mathrm{~d}$ of storage. Ethylene production continued to increase in both treatments throughout storage, with maximum production rates of $15.9 \pm 4.6$ and $10.4 \pm 3.5 \mu \mathrm{L} \cdot \mathrm{kg}^{-1} \cdot \mathrm{h}^{-1}$ observed for control (day 13) and 1-MCP-treated (day 21) fruit, respectively. Suppressed ethylene production in response to 1-MCP has been reported for several fruits, including 'Galia' melon (Ergun et al., 2005), avocado (Jeong et al., 2002), and climacteric stone fruits (Abdi et al., 1998; Fan et al., 2000). Other fruits respond differently, with ethylene production delayed but unaffected or enhanced in magnitude in avocado (Hershkovitz et al., 2005) and banana (Golding et al., 1998) and unaffected in timing and magnitude in persimmon (Diospyros kaki Thunb.; Ortiz et al., 2005) fruits. The effects of 1-MCP on ethylene production likely depend on the fruit, cultivar, stage of maturity or ripeness, and on whether ethylene synthesis is operating via negative or positive feedback regulation (system I vs. system II; Brummel, 2005).

Whereas ethylene production is variably affected by $1-\mathrm{MCP}$, respiration rates are typically reduced in response to the ethylene antagonist (Blankenship and Dole, 2003; Watkins, 2006). Consistent with observations for other fruits, respiration rates in 1-MCPtreated, preripe muskmelon were significantly reduced compared with those of control fruit, particularly during the first $11 \mathrm{~d}$ in storage (Fig. 3B). After $13 \mathrm{~d}$, the respiration of 1-MCP-treated fruit increased gradually, eventually attaining values $\left(9.3 \pm 0.9 \mathrm{~L} \cdot \mathrm{kg}^{-1} \cdot \mathrm{h}^{-1}\right)$ comparable to those observed for control fruit $\left(8.9 \pm 0.2 \mathrm{~mL} \cdot \mathrm{kg}^{-1} \cdot \mathrm{h}^{-1}\right)$ on the final day of storage.

Limitations in the quality of preripe ( $1 / 4$ slip) 'Athena' muskmelon include the low soluble solids concentration (SSC), which ranged between $8 \%$ and $9 \%$, and lack of intense aroma (assessed subjectively) upon reaching whole-fruit firmness values considered suitable for consumption $(50-75 \mathrm{~N})$. These observations are consistent with other reports for netted melons harvested at early $(1 / 4$ slip) maturity (Beaulieu et al., 2004; Lyons et al., 1962). In terms of firmness, electrolyte leakage, ethylene production and respiration, 1-MCP treatment was nonetheless effective in delaying the postharvest ripening of the Eastern-type 'Athena' muskmelon. In view of the low SSC and lack

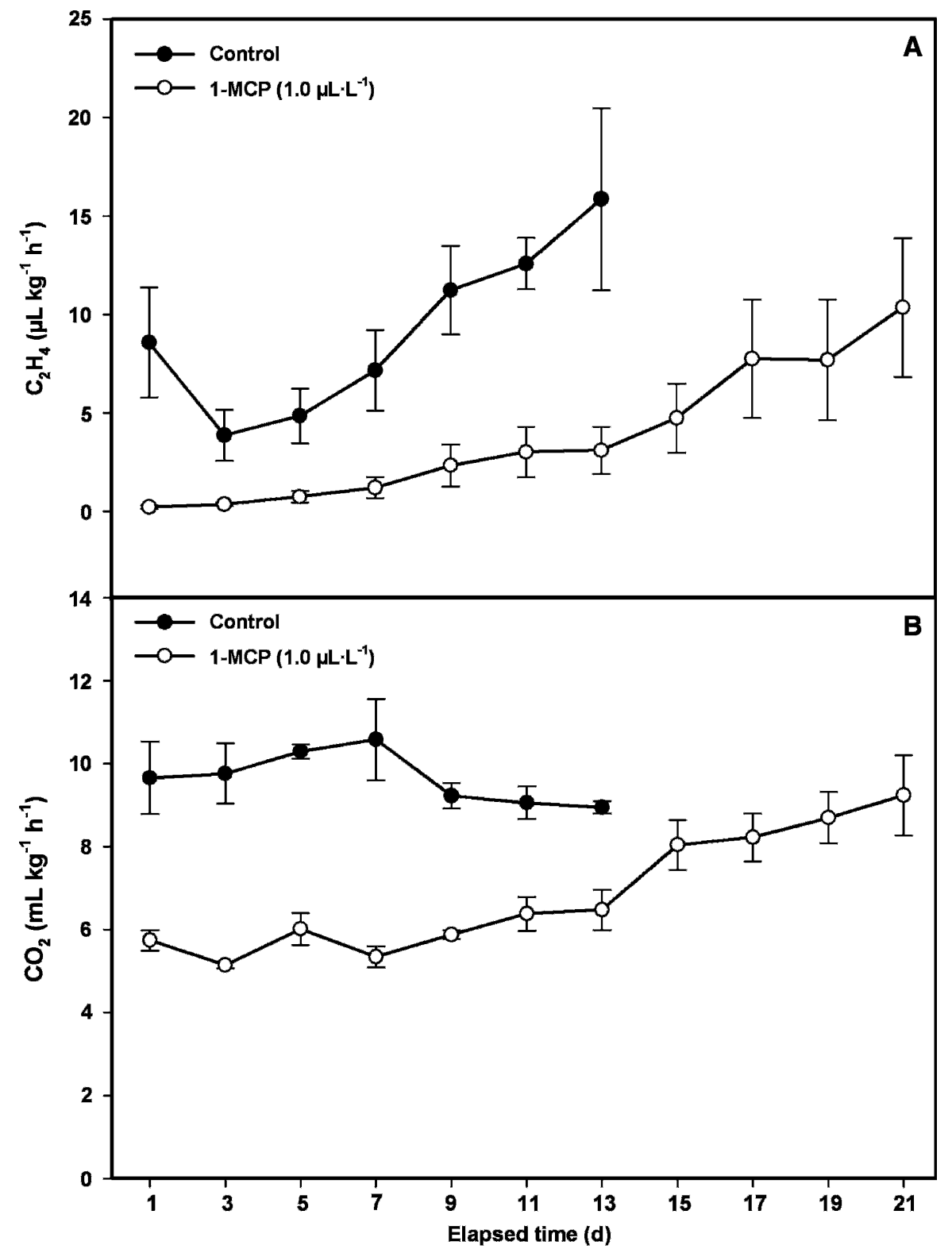

Fig. 3. Ethylene production (A) and respiration (B) of preripe 'Athena' muskmelon treated with air (control) or $1-\mathrm{MCP}$ at $1.0 \mu \mathrm{L} \cdot \mathrm{L}^{-1}$ for $18 \mathrm{~h}$ at $20^{\circ} \mathrm{C}$ and stored at $15{ }^{\circ} \mathrm{C}$. Vertical bars are standard deviations of means $(n=5)$. 
of intense aroma characteristics of preripe 'Athena' fruit, subsequent experiments addressed fruit harvested at more advanced maturity (half- and full-slip) and focused on firmness, arguably the most important determinant of shelf life and successful postharvest handling of these fruit.

1-MCP treatment of ripening 'Athena' cantaloupe. 'Athena' muskmelon harvested at half- or full-slip averaged $11 \%$ in soluble solids content, nearly $30 \%$ higher than average levels in preripe fruit and representing the minimum SSC for U.S. Fancy Grade (Shellie and Lester, 2004). Whole-fruit firmness values of half- and full-slip fruit at harvest averaged $\approx 15 \%$ and $35 \%$ lower, respectively, than those of preripe fruit at harvest. Ethylene production in the half and fullslip fruit, measured $24 \mathrm{~h}$ after harvest, averaged $12.6 \pm 5.4$ and $19.4 \pm 6.7 \mu \mathrm{L} \cdot \mathrm{kg}^{-1} \cdot \mathrm{h}^{-1}$, respectively.

1-MCP applied to half- and full-slip (Fig. 4) fruit was quite effective at decelerating the rate of whole-fruit softening during storage at $15{ }^{\circ} \mathrm{C}$. Differences between control and 1-MCP-treated fruit noted at day 6 (the first storage interval for measurement) were highly significant for both half- and fullslip fruit (Fig. 4). 1-MCP-treated half-slip 'Athena' had softened $\approx 6 \%$ after $6 \mathrm{~d}, 24 \%$ after $14 \mathrm{~d}$, and $40 \%$ after $19 \mathrm{~d}$ of storage. At $50 \mathrm{~N}$ firmness, these fruit at $19 \mathrm{~d}$ were in the low range of suitability for consumption. By contrast, control half-slip fruit softened $\approx 31 \%$ through $6 \mathrm{~d}$ and $>60 \%$ after $16 \mathrm{~d}$. Control half-slip fruit developed high incidence of watersoaking by 12-14 d, consistent with reaching whole-fruit firmness values (at or below $50 \mathrm{~N}$ ) below the range of acceptability. Despite lower initial firmness values at harvest $(64.3 \pm 3.3 \mathrm{~N})$ compared with preripe $(97.4 \pm 5.2 \mathrm{~N})$ and half-slip $(83.4 \pm 1.3 \mathrm{~N})$ fruit, fruit at more advanced ripening (full slip) remained highly responsive to 1-MCP. Full-slip fruit treated with 1-MCP retained acceptable quality (firmness) through $8 \mathrm{~d}$ of storage at $15{ }^{\circ} \mathrm{C}$, softening only $\approx 6 \%$. Control full-slip fruit rapidly reached firmness values outside the range of acceptability, softening 30\% through $8 \mathrm{~d}$.

A separate experiment with full-slip 'Athena' muskmelon was designed to simulate possible commercial handling protocols, including an intervening, 5-d low-temperature $\left(10^{\circ} \mathrm{C}\right)$ holding period before transfer to conditions approximating retail environments $\left(20^{\circ} \mathrm{C}\right)$. Flesh (mesocarp) firmness of full-slip 'Athena' muskmelon fruit treated for $24 \mathrm{~h}$ with $1-\mathrm{MCP}\left(1.0 \mu \mathrm{L} \cdot \mathrm{L}^{-1}\right)$ at $10^{\circ} \mathrm{C}$, held at $10^{\circ} \mathrm{C}$ for $5 \mathrm{~d}$, and then transferred to $20^{\circ} \mathrm{C}$ is shown in Fig. 5 Two days after transfer to $20{ }^{\circ} \mathrm{C}$, mesocarp firmness of control and 1 -MCP-treated fruit had declined $\approx 54 \%$ and $40 \%$ compared with values at the start of the experiment. After $4 \mathrm{~d}$, mesocarp tissue of control and 1-MCP-treated fruit had softened $70 \%$ and $42 \%$, respectively (Fig. 5). Based on $5 \mathrm{~N}$ as a minimal acceptable mesocarp firmness for consumption, shelf life at $20^{\circ} \mathrm{C}$ following $5 \mathrm{~d}$ holding at $10{ }^{\circ} \mathrm{C}$

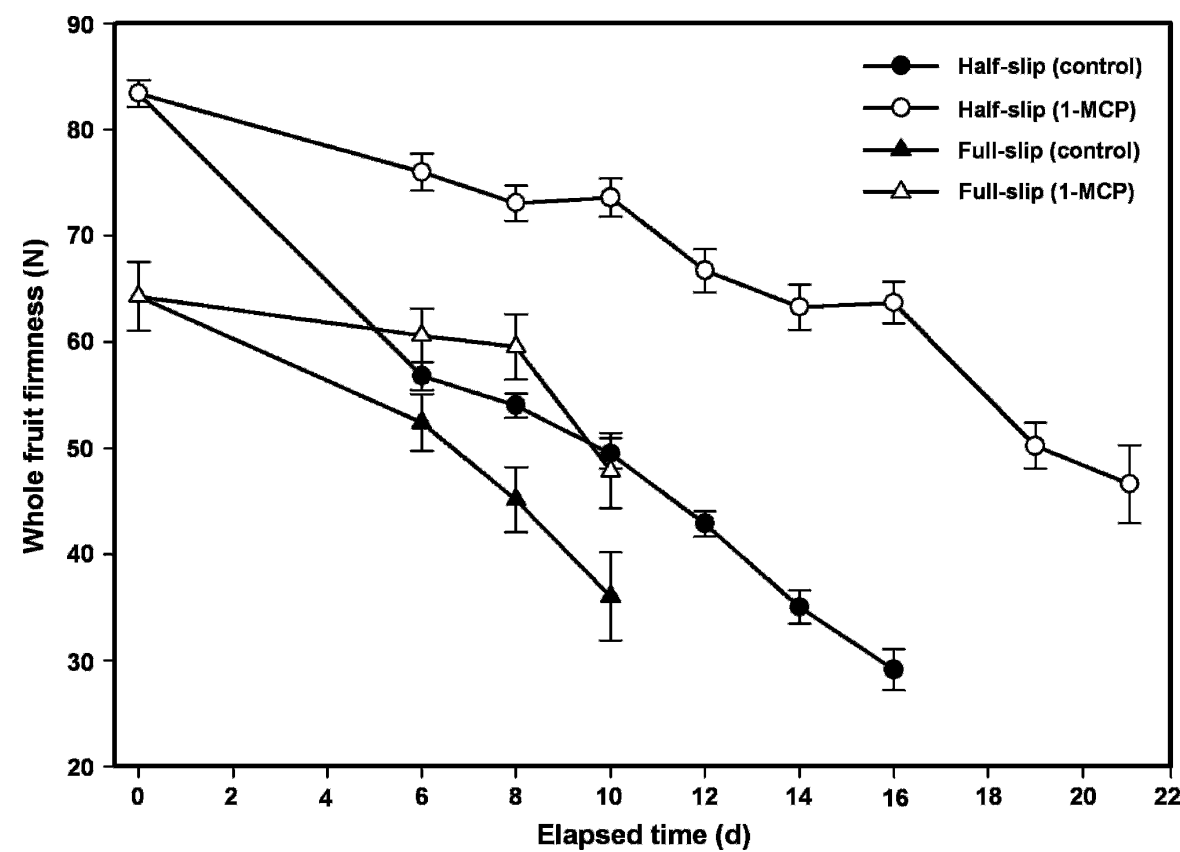

Fig. 4. Whole-fruit firmness (N) of half- and full-slip 'Athena' muskmelon treated with air (control) or $1-\mathrm{MCP}$ at $1.0 \mu \mathrm{L} \cdot \mathrm{L}^{-1}$ for $18 \mathrm{~h}$ at $20^{\circ} \mathrm{C}$ and stored at $15{ }^{\circ} \mathrm{C}$. Vertical bars are standard deviations of means ( $n=30,15$ fruit, 2 measurements per fruit).

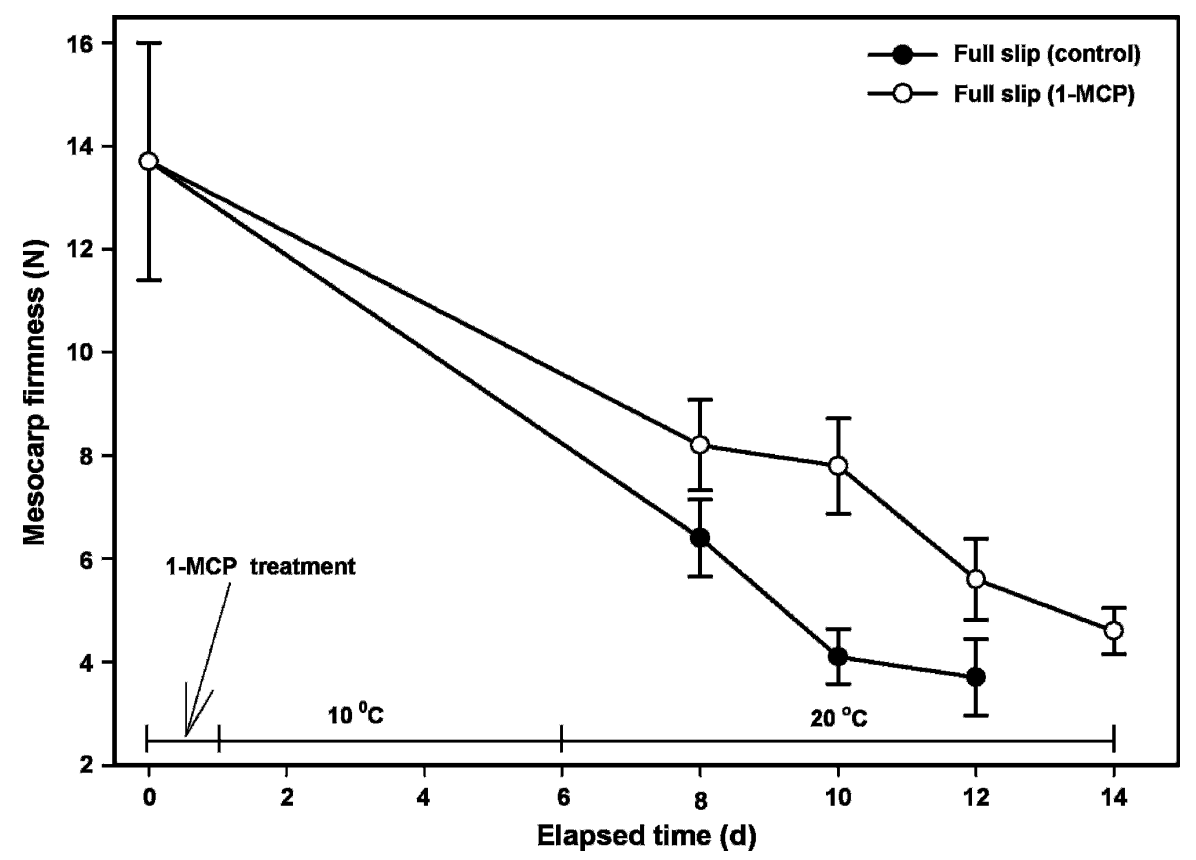

Fig. 5. Mesocarp firmness (N) of full-slip 'Athena' muskmelon treated for $24 \mathrm{~h}$ with 1-MCP $\left(1.0 \mu \mathrm{L} \cdot \mathrm{L}^{-1}\right)$ at $10^{\circ} \mathrm{C}$, held at $10^{\circ} \mathrm{C}$ for $5 \mathrm{~d}$, and then transferred to $20^{\circ} \mathrm{C}$. Vertical bars are standard deviations of means ( $n=15,5$ fruit, 3 measurements per fruit).

was $\approx 6$ and $2 \mathrm{~d}$ for $1-\mathrm{MCP}-$ treated and control fruit, respectively.

Tables 1 and 2 summarize the data for decay incidence and the appearance of depressed or sunken regions on the surface of 'Athena' muskmelon treated with 1-MCP at the full-slip stage, held at $10{ }^{\circ} \mathrm{C}$ for $5 \mathrm{~d}$, and transferred to $20^{\circ} \mathrm{C}$. While having no apparent influence on the incidence of these defects, 1-MCP significantly delayed their development. Suppression of ethylene action has been shown to have direct effects on specific pathogens (Diaz et al., 2002; Porat et al., 1999); however, the delay in pathogen incidence and surface defects in 'Athena' muskmelon was more likely the result of delayed ripening and softening.

The data herein indicate that 1-MCP has potential for commercial application for the perishable Eastern-type 'Athena' muskmelon, particularly fruit at advanced stages of development (half- to full-slip). The 
Table 1. Incidence (\%) of surface decay of full-slip 'Athena' muskmelon treated for $24 \mathrm{~h}$ with 1-MCP $\left(1.0 \mu \mathrm{L} \cdot \mathrm{L}^{-1}\right)$ at $10{ }^{\circ} \mathrm{C}$, held at $10{ }^{\circ} \mathrm{C}$ for $5 \mathrm{~d}$, and then transferred to $20^{\circ} \mathrm{C}$. ${ }^{z}$

Elapsed time at $20^{\circ} \mathrm{C}$

Treatment \begin{tabular}{lllll}
\cline { 2 - 5 } 0 & Day 2 & Day 4 & Day 6 & Day 8 \\
\hline
\end{tabular}

\begin{tabular}{llllll}
\hline Air & 10 & 20 & 26.7 & 33.3 & 100
\end{tabular}

$\begin{array}{llllll}1-\mathrm{MCP} & 0 & 10 & 13.3 & 16.7 & 20\end{array}$

zPercentages are based on the number of fruit exhibiting sunken areas divided by the total number of fruit multiplied by 100 . Thirty fruit were measured at each interval.

Table 2. Incidence (\%) of full-slip 'Athena' muskmelon fruit displaying sunken regions during storage following treatment for $24 \mathrm{~h}$ with 1 -MCP $\left(1.0 \mu \mathrm{L} \cdot \mathrm{L}^{-1}\right)$ at $10^{\circ} \mathrm{C}$, held at $10^{\circ} \mathrm{C}$ for $5 \mathrm{~d}$, and then transferred to $20^{\circ} \mathrm{C}$.

\begin{tabular}{lccccc}
\hline & \multicolumn{5}{c}{ Elapsed time at $20^{\circ} \mathrm{C}$} \\
\cline { 2 - 6 } Treatment & Day 0 & Day 2 & Day 4 & Day 6 & Day 8 \\
\hline Air & 0 & 0 & 36.7 & 63.3 & 100 \\
1-MCP & 0 & 0 & 16.7 & 33.3 & 60 \\
\hline
\end{tabular}

${ }^{2}$ Percentages are based on the number of fruit exhibiting sunken areas divided by the total number of fruit multiplied by 100 . Thirty fruit were measured at each interval.

efficacy of ethylene action inhibitors including 1-MCP varies significantly with fruit maturity (Blankenship and Dole, 2003; Watkins, 2006), with greater and sometimes irreversible responses noted for fruit treated at less-advanced maturity. This is consistent with observations that ethylene plays an obligatory role in synchronizing ripening initiation. The inability of 'Galia' melon (Ergun et al., 2005) and banana fruits (Golding et al., 1998) to degreen and tomato fruit to soften normally (Hurr et al., 2005) represent examples of adverse, irreversible effects of 1MCP application before the full engagement of ripening processes. On the other hand, because retention of firm, crisp texture is a desirable characteristic in fruits such as apple, 1-MCP application at a preclimacteric stage has generally not been problematic (Watkins, 2006). Depending on the extent to which the progression and completion of ripening is dependent on ethylene, treatment of fruits with 1-MCP at advanced stages of ripening might circumvent problems related to incomplete recovery from the effects of 1-MCP applied to fruit of less-advanced maturity. Application of 1-MCP effectively and transiently delayed softening and red color development in tomato fruit at progressively advanced stages of ripening (Hoeberichts et al., 2002; Hurr et al., 2005) and softening and over-ripening of nearly ripe papaya (Carica papaya L.; Ergun and Huber, 2004) and 'Galia' melon (Cucumis melo var. reticulatus L.; Ergun et al., 2005) fruits. 'Redchief Delicious' apple fruit also responded to 1-MCP applied after the onset of climacteric ethylene production, with beneficial effects on firmness persisting for $>100$ $\mathrm{d}$ for fruit held at low temperatures or subjected to multiple exposures to the ethylene antagonist (Mir et al., 2001).

In conclusion, 'Athena' cantaloupe represents yet another fruit that exhibits a strong response to $1-\mathrm{MCP}$ after the initiation of ripening. It is noteworthy that persistence of 1-MCP efficacy when applied after the initiation of ripening is not characteristic of all climacteric fruit. Ripening (monitored as softening) of avocado fruit was recalcitrant to $1-\mathrm{MCP}$ applied beyond $48 \mathrm{~h}$ following ripening initiation (Adkins et al., 2005), and the effects of 1-MCP on banana fruit were significantly diminished when applied $24 \mathrm{~h}$ (Golding et al., 1998) after ripening initiation. Treatment of preripe fruit $(1 / 4 \mathrm{slip})$ 'Athena' resulted in low aroma profiles as well as persistence of whole-fruit firmness (at or above $80 \mathrm{~N}$ ) at values in excess of those judged suitable for consumption. Firmness of fruit at more advanced ripening ( $1 / 2$ and full slip) was significantly retained in response to $1-\mathrm{MCP}$, and values remained within a general window of acceptability (50-75 N) for $\approx 8 \mathrm{~d}$ compared with 5-6 d for control fruit. Based on the period of extended firmness retention and general competence to ripen (satisfactory aroma, low incidence of surface defects), fruit at the half-slip, or more advanced maturity stages, would appear most suited for 1-MCP adoption in commercial settings.

\section{Literature Cited}

Abdi, N., W.B. McGlasson, P. Holford, M. Williams, and Y. Mizrahi. 1998. Responses of climacteric and suppressed-climacteric plums to treatment with propylene and 1-methylcyclopropene. Postharvest Biol. Technol. 14: 29-39.

Adkins, M.F., P.J. Hofman, B.A. Stubbings, and A.J. Macnish. 2005. Manipulating avocado fruit ripening with 1-methylcyclopropene. Postharvest Biol. Technol. 35:33-42.

Beaulieu, J.C., D.A. gram, J.M. Lea, and K.L. BettGarber. 2004. Effect of harvest maturity on the sensory characteristics fresh-cut cantaloupe. J. Food Sci. 69:S250-S258

Blankenship, S.M. and J.M. Dole. 2003. 1-Methylcyclopropene: a review. Postharvest Biol. Technol. 28:1-25.

Brummell, D. 2005. Regulation and genetic manipulation of ripening in climacteric fruit. Stewart Postharvest Rev. 31. http://www.stewartpos tharvest.com/

Diaz, J., A. Ten Have, and J.A.L. Van Kan. 2002 The role of ethylene and wound signaling in resistance of tomato to Botrytis cinerea. Plant Physiol. 129:1341-1351.

Ergun, M. and D.J. Huber. 2004. Suppression of ethylene perception extends shelf-life and quality of 'Sunrise Solo' papaya fruit at both preripe and ripe stages of development. Europ. J. Hort. Sci. 69:184-192.

Ergun, M., J. Jeong, D.J. Huber, and D.J. Cantliffe. 2005. Suppression of ripening and softening of 'Galia' melons by 1-methylcyclopropene applied at preripe or ripe stage of development. HortScience 40:170-175.

Fan, X., L. Argenta, and J.P. Mattheis. 2000. Inhibition of ethylene action by 1-methylcyclopropene prolongs storage life of apricots. Postharvest Biol. Technol. 20:135-142.

Flores, F., M. Ben-Amor, B. Jones, J.C. Pech, M. Bouzayen, A. Latche, and F. Romojaro. 2001. The use of ethylene-suppressed lines to assess differential sensitivity to ethylene of the various ripening pathways in cantaloupe melons. Physiol. Plant. 113:128-133.
Golding, J.B., D. Shearer, S.G. Wyllie, and W.B. McGlasson. 1998. Application of 1-MCP and propylene to identify ethylene-dependent ripening processes in mature banana fruit. Postharvest Biol. Technol. 14:87-98.

Hershkovitz, V., S.I. Saguy, and E. Pesis. 2005. Postharvest application of 1-MCP to improve the quality of various avocado cultivars. Postharvest Biol. Technol. 37:252-264.

Hoeberichts, F.A., L.H.W. Van Der Plas, and E.J. Woltering. 2002. Ethylene reception is required for expression of tomato ripening-related genes and associated physiological changes even at advanced stages of ripening. Postharvest Biol. Technol. 26:125-133.

Huber, D.J. 2007. Suppression of ethylene responses through application of 1-methylcyclopropene: a powerful tool for elucidating ripening and senescence mechanisms in climacteric and nonclimacteric fruits and vegetables. HortScience. (In press)

Hurr, B.M., D.J. Huber, and J.H. Lee. 2005 Differential responses in color changes and softening of 'Florida 47' tomato fruit treated at green and advanced ripening stages with the ethylene antagonist 1-methylcyclopropene. HortTechnology 15:617-622.

Jeong, J., J.K. Brecht, D.J. Huber, and S.A. Sargent. 2004. 1-Methylcyclopropene (1-MCP) for extending shelf-life and maintaining quality of fresh-cut tomato. HortScience 39: 1359-1362.

Jeong, J., D.J. Huber, and S. Sargent. 2002. Influence of 1-methylcyclopropene (1-MCP) on ripening and cell-wall matrix polysaccharides of avocado (Persea americana) fruit. Postharvest Biol. Technol. 25:241-256.

Jiang, Y., D.C. Joyce, and A.J. Macnish. 1999. Responses of banana fruit to treatment with 1-methylcyclopropene. Plant Growth Regulat. 28:77-82.

Jiang, Y.M., D.C. Joyce, W.B. Jiang, and W.J. Lu. 2004. Effects of chilling temperatures on ethylene binding by banana fruit. Plant Growth Regulat. 43:109-115.

Lacan, D. and J.C. Baccou. 1996. Changes in lipids and electrolyte leakage during nonnetted muskmelon ripening. J. Amer. Soc. Hort. Sci. 121:554-558.

Lelievre, J.-M., A. Latche, B. Jones, M. Bouzayen, and J.-C. Pech. 1997. Ethylene and fruit ripening. Physiol. Plant. 101:727-739.

Lester, G. 1996. Calcium alters senescence rate of postharvest muskmelon fruit disks. Postharvest Biol. Technol. 7:91-96.

Lester, G. and E. Stein. 1993. Plasma membrane physicochemical changes during maturation and postharvest storage of muskmelon fruit. J. Amer. Soc. Hort. Sci. 118:223-227.

Lyons, J.M., W.B. McGlasson, and H.K. Pratt. 1962. Ethylene production, respiration, and internal gas concentrations in cantaloupe fruits at various stages of maturity. Plant Physiol. 37:31-36.

Mir, N.A., E. Curell, N. Khan, M. Whitaker, and R.M. Beaudry. 2001. Harvest maturity, storage temperature, and 1-MCP application frequency alter firmness retention and chlorophyll fluorescence of 'Redchief Delicious' apples. J. Amer. Soc. Hort. Sci. 126:618-624.

Mao, L., Y. Karakurt, and D.J. Huber. 2004 Incidence of water-soaking and phospholipid catabolism in ripe watermelon (Citrullus lanatus) fruit: induction by ethylene and prophylactic effects of 1-methylcyclopropene. Postharvest Biol. Technol. 33:1-9.

Ortiz, G.I., S. Sugaya, Y. Sekozawa, H. Ito, K. Wada, and H. Gemma. 2005. Efficacy of 
1-methylcyclopropene (1-MCP) in prolonging the shelf-life of 'Rendaiji' persimmon fruits previously subjected to astringency removal treatment. J. Jap. Soc. Hort. Sci. 74:248254.

Porat, R., B. Weiss, L. Cohen, A. Daus, R. Goren, and S. Droby. 1999. Effects of ethylene and 1-methylcyclopropene on the postharvest qualities of 'Shamouti' oranges. Postharvest Biol. Technol. 15:155-163.

SAS Institute. 1985. SAS/STAT guide for personal computers. Version 6. SAS Inst., Cary, NC.
Seymour, G.B. and W.B. McGlasson. 1993. Melons, p. 273-290. In: G. Seymour, J. Taylor, and G. Tucker (eds.). Biochemistry of fruit ripening. Chapman and Hall, Cambridge University Press, U.K.

Shackel, K.A., C. Greve, J.M. Labavitch, and H. Ahmadi. 1991. Cell turgor changes associated with ripening in tomato pericarp tissue. Plant Physiol. 97:814-816.

Shellie, K.C. and G. Lester. 2004. Netted melons. In: K.C. Gross, C.Y. Wang, and M. Saltveit (eds.). The commercial storage of fruits, vegetables, and florist and nursery stocks. USDA
Agriculture Handbook Number 66. http:// www.ba.ars.usda.gov/hb66.

Sisler, E.C. 2006. The discovery and development of compounds counteracting ethylene at the receptor level. Biotechnol. Adv. 24: 357-367.

Watkins, C.B. 2006. The use of 1-methylcyclopropene (1-MCP) on fruits and vegetables. Biotechnol. Adv. 24:389-409.

Wills, R.B.H. and V.V.V. Ku. 2002. Use of 1-MCP to extend the time to ripen of green tomatoes and postharvest life of ripe tomatoes. Postharvest Biol. Technol. 26:85-95. 